\title{
Sistem Informasi Kearsipan Dokumen Kepegawaian Pada Universitas Maritim AMNI Semarang
}

Muhammad Hanif ${ }^{1}$, Felix Andreas Sutanto ${ }^{2}$

${ }^{1}$ Teknik Informatika - Unisbank Semarang, hanifhan12345@gmail.com

${ }^{2}$ Teknik Informatika - Unisbank Semarang, felix@ unisbank.ac.id

Jalan Tri Lomba Juang Semarang, Telp. (024) 8451976

\begin{tabular}{|c|c|}
\hline ARTICLE INFO & ABSTRACT \\
\hline $\begin{array}{l}\text { Article history: } \\
\text { Received Nov } 2021 \\
\text { Received in revised form Nov } 2021 \\
\text { Accepted Des } 2021 \\
\text { Available online Des } 2021\end{array}$ & $\begin{array}{l}\text { There are many archives owned by AMNI Maritime } \\
\text { University in Semarang. The archiving system } \\
\text { carried out at the AMNI Maritime University } \\
\text { Semarang is still not well organized and neat } \\
\text { because it is only based on archive classification, so } \\
\text { if you have to look for archives such as archive } \\
\text { numbers or archive dates, you will experience } \\
\text { problems because you have to find the files needed } \\
\text { one by one in the filing cabinet. The sequential } \\
\text { search algorithm can be applied to the search for } \\
\text { employee document numbers at the Maritime } \\
\text { University AMNI Semarang and works well as } \\
\text { planned. The employee document archive } \\
\text { information system at the Maritime University } \\
\text { AMNI Semarang can be used to manage the } \\
\text { employee document archive more optimally, } \\
\text { controlled, well organized and maintained so that the } \\
\text { archive is not easily damaged }\end{array}$ \\
\hline
\end{tabular}

Keywords: Archives, AMNI Maritime University Semarang, Sequential Search Algorithm

\section{PENDAHULUAN}

Arsip merupakan suatu bagian yang penting dalam suatu organisasi atau dalam suatu instansi, karena arsip adalah sebuah informasi kegiatan atau aktivitas yang selalu terjadi secara terus menerus. Arsip adalah bagian yang tidak dapat terpisahkan dalam suatu organisasi atau instansi karena arsip ini dapat menunjukkan bahwa ada suatu kegiatan atau aktivitas yang terjadi dan menghasilkan suatu informasi [1]. Kearsipan memiliki peranan selaku pusat ingatan, sumber data serta selaku perlengkapan pengawasan yang sangat dibutuhkan dalam tiap organisasi dalam rangka aktivitas perencanaan, penganalisaan, formulasi kebijakan, pembuatan laporan, pengambilan keputusan ataupun evaluasi [2].

Arsip seharusnya disimpan, dipelihara dan diatur agar dapat menunjang kegiatan administrasi. Hal ini menunjukkan bahwa arsip merupakan sumber informasi tentang masa lalu yang sangat berguna sebagai dasar pengambilan keputusan di masa sekarang dan masa yang akan datang [2]

Arsip yang ditata secara sistematis hendak membagikan kemudahan dalam mencari data tentang permasalahan yang berhubungan dengan segala aktivitas yang sudah dicoba oleh Universitas Maritim AMNI Semarang. Banyak yang belum menguasai berartinya suatu arsip sehingga kerap kali ditemui bermacam dokumen tertulis yang ditaruh secara sembarangan, Received Nov, 2021; Revised Nov, 2021; Accepted Des, 2021 
penyimpanan yang tidak terorganisir ataupun apalagi dibuang ke tempat sampah sebab arsip cuma dikira tumpukan kertas yang tidak terpakai yang wajib dibundel serta dimasukkan ke gudang ataupun terbakar selaku sampah. Pemahaman tentang berartinya suatu arsip baru dialami dikala arsip tersebut dibutuhkan buat kebutuhan tertentu namun sangat susah menciptakannya kembali.

Arsip yang dimiliki Universitas Maritim AMNI Semarang sangatlah banyak. Sistem pengarsipan yang dilakukan pada Universitas Maritim AMNI Semarang masih belum tersusun dengan baik dan rapi karena hanya berdasarkan klasifikasi arsip saja sehingga jika harus mencari arsip seperti no arsip ataupun tanggal arsip akan mengalami kendala karena harus mencari satu persatu arsip yang dibutuhkan pada lemari arsip. Penelitian ini memfokuskan hanya mengenai manajemen kearsipan dokumen kepegawaian dosen dan karyawan Universitas Maritim AMNI Semarang. Semakin banyaknya arsip dokumen kepegawaian yang dimiliki oleh Universitas Maritim AMNI Semarang maka semakin banyak masalah yang ditemukan karena proses pencarian arsip masih dilakukan secara manual yaitu dengan mencari satu per satu arsip yang dibutuhkan pada lemari arsip. Berdasarkan hasil pengamatan tentang manajemen kearsipan dan pencarian arsip di Universitas Maritim AMNI Semarang belum bisa dikatakan baik. Petugas arsip akan kesulitan mencari arsip yang dibutuhkan sebab minimnya penyusunan arsip yang baik.

Pencarian merupakan proses yang fundamental dalam pengolahan data. Sequential search merupakan algoritma pencarian beruntun yang prosesnya membandingkan setiap elemen satu persatu secara beruntun, mulai dari elemen pertama sampai elemen yang di cari di temukan atau seluruh elemen sudah di periksa [3]. Tujuan dari penelitian ini yaitu mengimplementasikan algoritma sequential search untuk mempermudah pencarian dokumen kepegawaian dosen dan karyawan di Universitas Maritim AMNI Semarang.

Pencarian ialah proses yang fundamental dalam pengolahan data. Sequential search ialah algoritma pencarian beruntun yang prosesnya menyamakan tiap elemen satu persatu secara beruntun, mulai dari elemen awal hingga elemen yang di cari di temukan ataupun segala elemen telah di cek [3]. Tujuan dari riset ini ialah mengimplementasikan algoritma sequential search supaya memudahkan pencarian dokumen kepegawaian dosen serta karyawan di Universitas Maritim AMNI Semarang.

\section{TINJAUAN PUSTAKA}

Penelitian yang dilakukan oleh [4] menjelaskan bahwa bagian tata usaha Fakultas Teknik Universitas Bengkulu masih menggunakan cara manual dalam penanganan dan pengarsipan nomor surat yaitu penomoran surat baru dengan cara mencatat (tulisan tangan) di buku dan mengecek urutan abjad sebelumnya. Cara ini tentu tidak efisien, karena membutuhkan buku yang tebal, terutama untuk arsip jangka panjang, dan banyak jenis surat yang harus diarsipkan. Tujuan dari penelitian ini adalah untuk mengimplementasikan algoritma pencarian sekuensial untuk mempermudah pencarian nomor huruf pada sistem arsip elektronik studi kasus administrasi Fakultas Teknik Universitas Bengkulu. Dilihat dari analisis, perancangan, pengujian, dan implementasi program aplikasi arsip elektronik, program aplikasi dapat berjalan dengan normal. Algoritma pencarian sekuensial dapat diimplementasikan dalam pencarian arsip berdasarkan nomor surat pada surat masuk dan surat keluar.

Penelitian yang dilakukan oleh [5] Dijelaskan bahwa Puskesmas Kampung Bali masih secara manual memberikan pelayanan kepada pasien, seperti pencarian data pasien, pengelolaan data pasien, penggunaan formulir pencatatan pemeriksaan pasien, penggunaan pembukuan manual untuk pengelolaan laporan data pemeriksaan dan data obat. Media penyimpanan data pasien menggunakan media berbasis kertas, sehingga pencarian data dilakukan melalui file tracking, yang mungkin memakan waktu lama, dan masih dilakukan secara manual dengan cara penyajian kembali data pasien melalui file, yang tidak hanya rawan error., tetapi juga memakan waktu. Sistem yang dibangun dapat digunakan untuk mencatat dan mencari data pasien, 
pemeriksaan pasien dan data pengobatan sehingga Puskesmas dapat dengan mudah mengarsipkan data pemeriksaan yang bersifat rahasia.

Penelitian lain tentang sequential search juga dilakukan oleh [6] menjelaskan proses pencarian kata kamus dalam bentuk buku bisa memakan waktu lama karena proses pencariannya manual. Tujuan dari penelitian ini adalah menggunakan metode sequential search untuk membuat aplikasi kamus tiga bahasa berbasis Android untuk bahasa Jawa Ngoko, Jawa Krama, dan Bahasa Indonesia. Metode pencarian ini dilakukan dengan mengurutkan dari indeks pertama hingga record yang ditemukan. Hasil penelitian ini tersedia dalam bentuk aplikasi kamus bahasa Jawa Ngoko, Krama Jawa, dan bahasa Indonesia dengan menggunakan metode pencarian sekuensial. Metode ini dapat mencari sekitar 2730 kata dan setiap pencarian $100 \%$ akurat. Setiap pencarian membutuhkan rata-rata 0,5 detik untuk menemukan catatan yang membantu pengguna memahami dan mempelajari bahasa Jawa Indonesia.

\section{METODE PENELITIAN}

\subsection{Algoritma Sequential Search}

Proses algoritma sequential search pada pencarian dokumen kepegawaian pada Universitas Maritim AMNI Semarang adalah sebagai berikut:

a. Pertama dilakukan perbandingan satu per satu secara berurutan dalam kumpulan data yang berisi nomor dokumen kepegawaian dengan nomor dokumen kepegawaian yang di cari sampai nomor dokumen kepegawaian tersebut ditemukan atau tidak ditemukan.

b. Pada dasarnya, pencarian ini hanya melakukan pengulangan data dari 1 sampai dengan jumlah data (n) pada dokumen kepegawaian.

c. Setiap pengulangan, dibandingkan nomor surat ke-I dengan nomor dokumen kepegawaian yang sedang dicari.

d. Apabila nomor dokumen kepegawaian sama dengan yang dicari, berarti dokumen kepegawaian telah berhasil di temukan. Sebaliknya apabila sampai akhir melakukan pengulangan tidak ada data yang sama dengan yang dicari, berarti data tidak ada yang ditemukan.

Flowchart dari pencarian dokumen kepegawaian pada Universitas Maritim AMNI Semarang diperlihatkan seperti gambar 3.1.

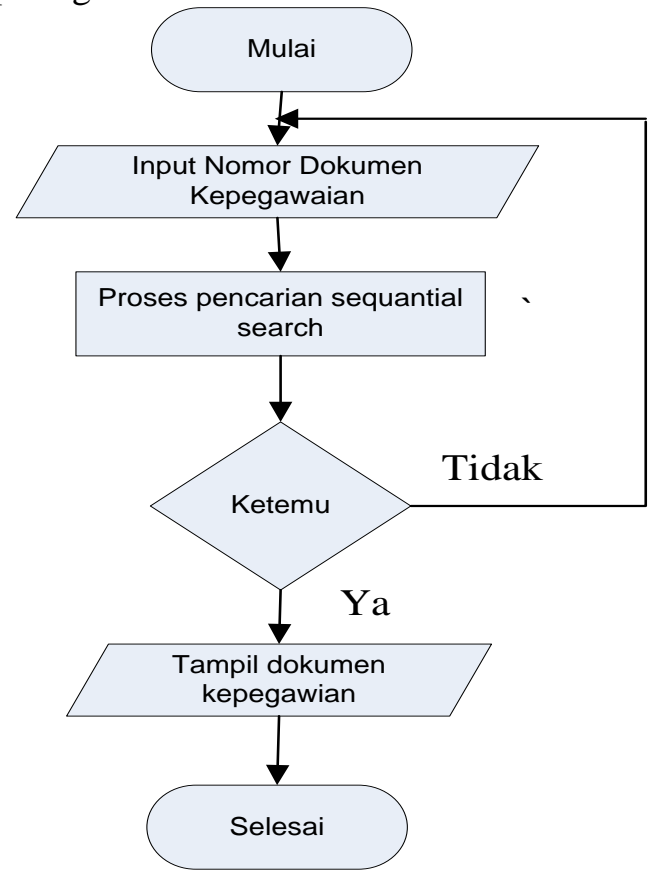

Sistem Informasi Kearsipan Dokumen Kepegawaian Pada Universitas Maritim AMNI Semarang 
Gambar 3.1. Flowchart Pencarian Dokumen Kepegawaian

Urutan Algoritma sequential search pada dokumen kepegawaian pada Universitas Maritim AMNI Semarang adalah sebagai berikut:

a. $\mathrm{i}<-0$

b. Ketemu $<-$ false

c. Selama ( tidak ketemu ) dan $(\mathrm{i}<\mathrm{N})$ kerjakan baris $\mathrm{d}$

d. Jika ( Data[i] = key ) maka ketemu <- true, jika tidak i <- i + 1

e. Jika ( Ketemu ) maka i adalah indeks dari data yang dicari

Proses pencarian dokumen kepegawaian pada gambar 3.1 dimulai dari pengguna memasukkan nomor dokumen kepegawaian yang ingin dicari, kemudian sistem akan melakukan pencarian menggunakan algoritma sequential search. Jika dokumen kepegawaian ditemukan dari nomor dokumen kepegawaian yang dicari maka sistem akan menampilkan dokumen kepegawaian sedangkan jika tidak ditemukan maka pengguna dapat mengulang pencarian dokumen kepegawaian dengan mengisi nomor dokumen kepegawaian yang baru.

\subsection{Analisis Permasalahan}

Permasalahan pengelolaan kearsipan dokumen kepegawaian pada Universitas Maritim AMNI Semarang yaitu:

a. Sistem pengarsipan yang dilakukan pada Universitas Maritim AMNI Semarang masih belum tersusun dengan baik dan rapi karena hanya berdasarkan klasifikasi arsip saja.

b. Proses pencarian arsip dokumen kepegawaian masih dilakukan secara manual.

c. Pengelolaan arsip dokumen kepegawaian yang belum terpusat tetapi masih disimpan disimpan di masing-masing bidang yang berkepentingan

Dengan masalah tersebut, penelitian ini akan membuat sistem yang mampu mengelola dan mencari arsip dokumen kepegawaian pada Universitas Maritim AMNI Semarang dengan algoritma sequential search sehingga manajemen dan pencarian arsip dokumen kepegawaian dosen dan karyawan menjadi lebih terkontrol, tertata dengan baik dan terawat sehingga arsip tidak mudah rusak.

\subsection{Analisis Kebutuhan Data dan Informasi}

Analisis kebutuhan informasi pada sistem informasi kearsipan dokumen kepegawaian pada Universitas Maritim AMNI Semarang terdiri dari kebutuhan data dan kebutuhan informasi.

A. Kebutuhan Data

Kebutuhan data pada sistem informasi kearsipan dokumen kepegawaian pada Universitas Maritim AMNI Semarang yaitu
a. Data klasifikasi
b. Data lemari
c. Data rak
d. Data baris
e. Data dosen dan karyawan
f. Data dokumen kepegawaian

B. Kebutuhan Informai

Kebutuhan informasi pada sistem informasi kearsipan dokumen kepegawaian pada Universitas Maritim AMNI Semarang yaitu
a. Laporan dosen dan karyawan
b. Laporan dokumen kepegawaian

\subsection{Use Case Diagram}

Use case diagram [7] sistem informasi kearsipan dokumen kepegawaian pada Universitas Maritim AMNI Semarang terdiri dari 1 aktor yaitu arsiparis. Arsiparis melakukan login kemudian dapat mencari arsip atau melakukan pengelolaan data klasifikasi, data lemari, data rak, data baris, data dosen dan karyawan, data dokumen kepegawaian, cetak laporan atau keluar dari sistem 


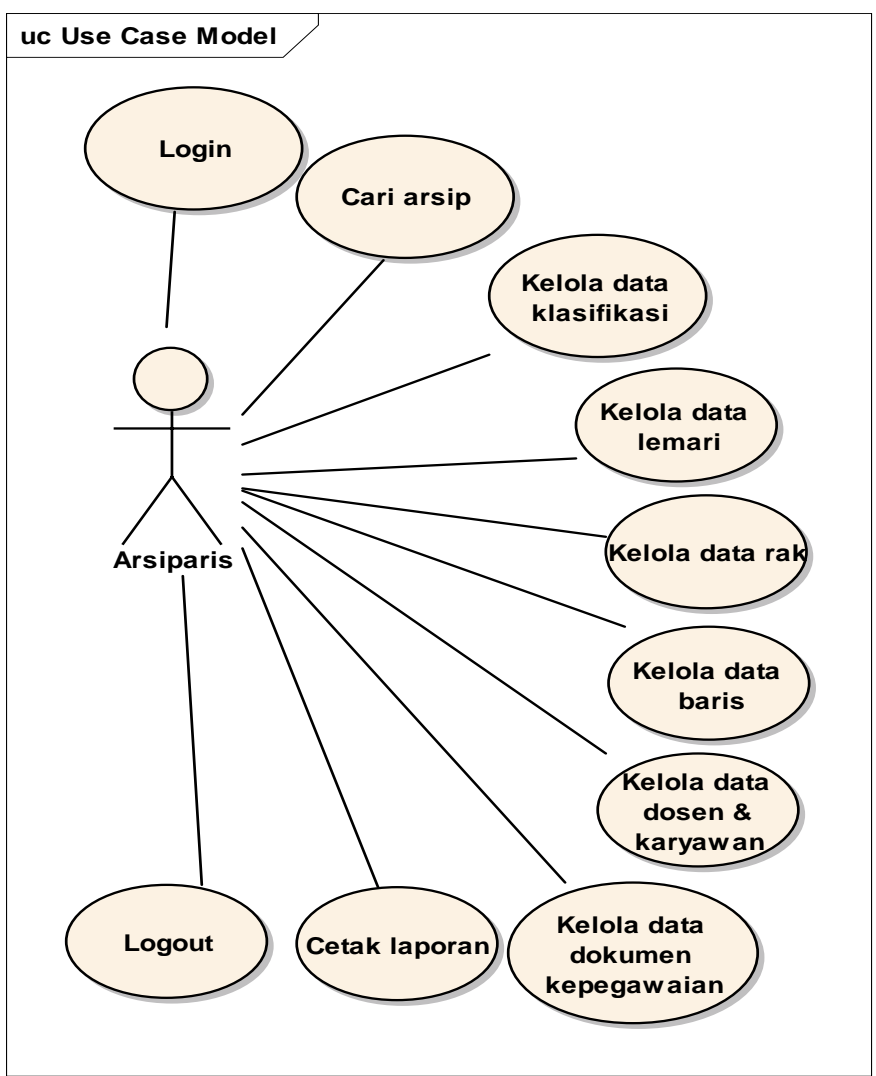

Gambar 3.2. Use Case Diagram

\subsection{Activity Diagram}

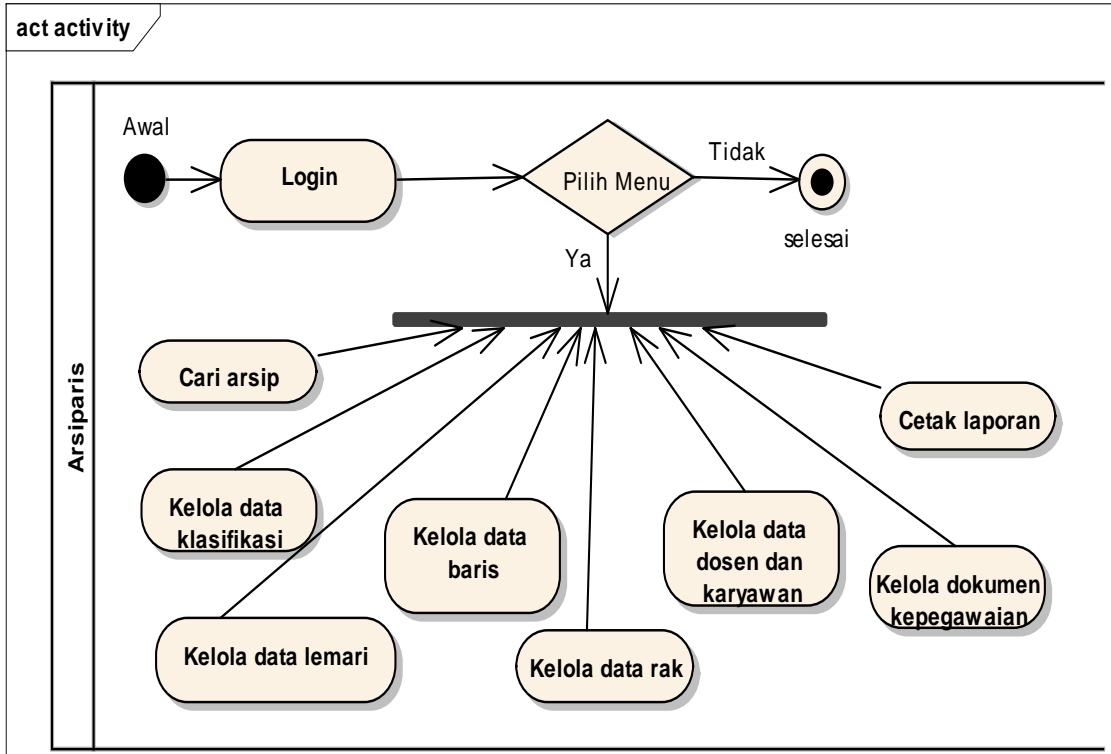

Gambar 3.3. Activity Diagram

Activity diagram [7] sistem informasi kearsipan dokumen kepegawaian pada Universitas Maritim AMNI Semarang dimulai dari arsiparis melakukan login kemudian dapat mencari arsip 
atau melakukan pengelolaan data klasifikasi, data lemari, data rak, data baris, data dosen dan karyawan, data dokumen kepegawaian, cetak laporan atau keluar dari sistem.

\subsection{Sequence Diagram}

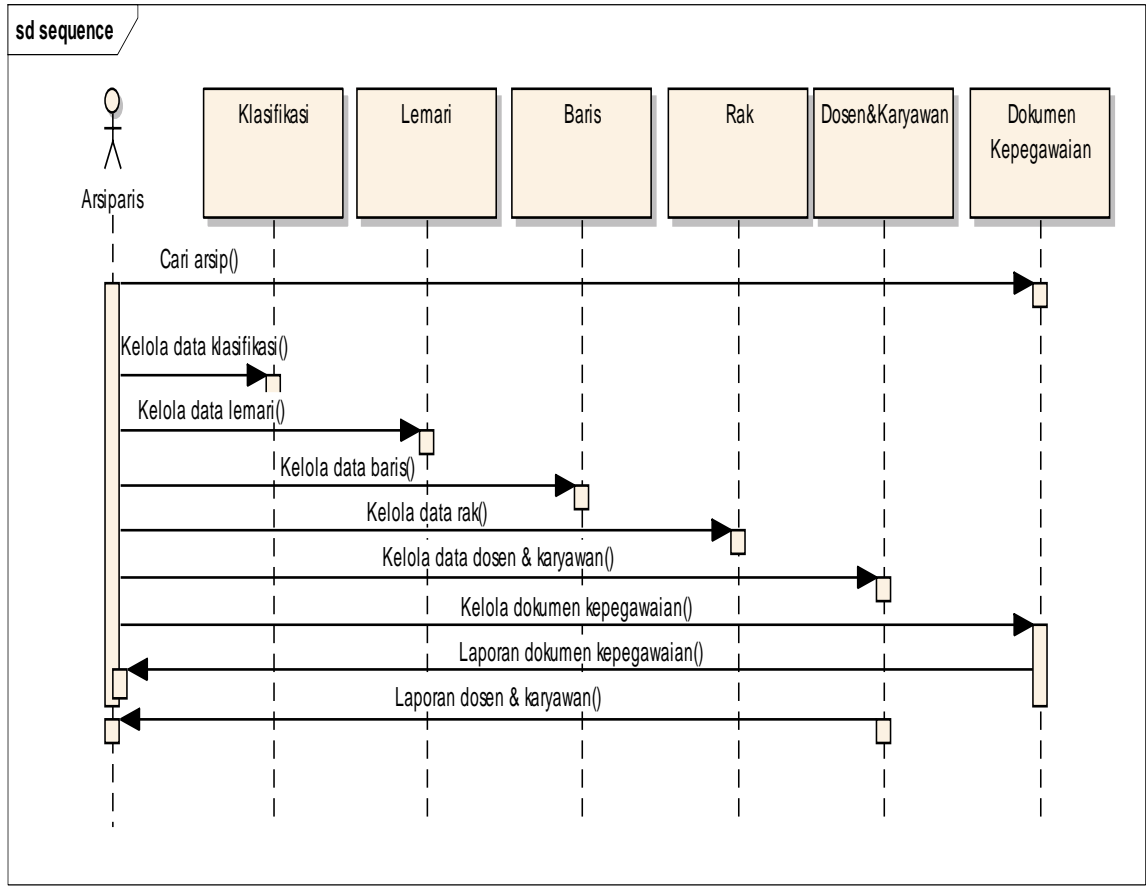

Gambar 3.4. Sequence Diagram

Sequence diagram [7] sistem informasi kearsipan dokumen kepegawaian pada Universitas Maritim AMNI Semarang dimulai dari arsiparis melakukan login kemudian dapat mencari arsip atau melakukan pengelolaan data klasifikasi, data lemari, data rak, data baris, data dosen dan karyawan, data dokumen kepegawaian, cetak laporan atau keluar dari sistem.

\subsection{Class Diagram}

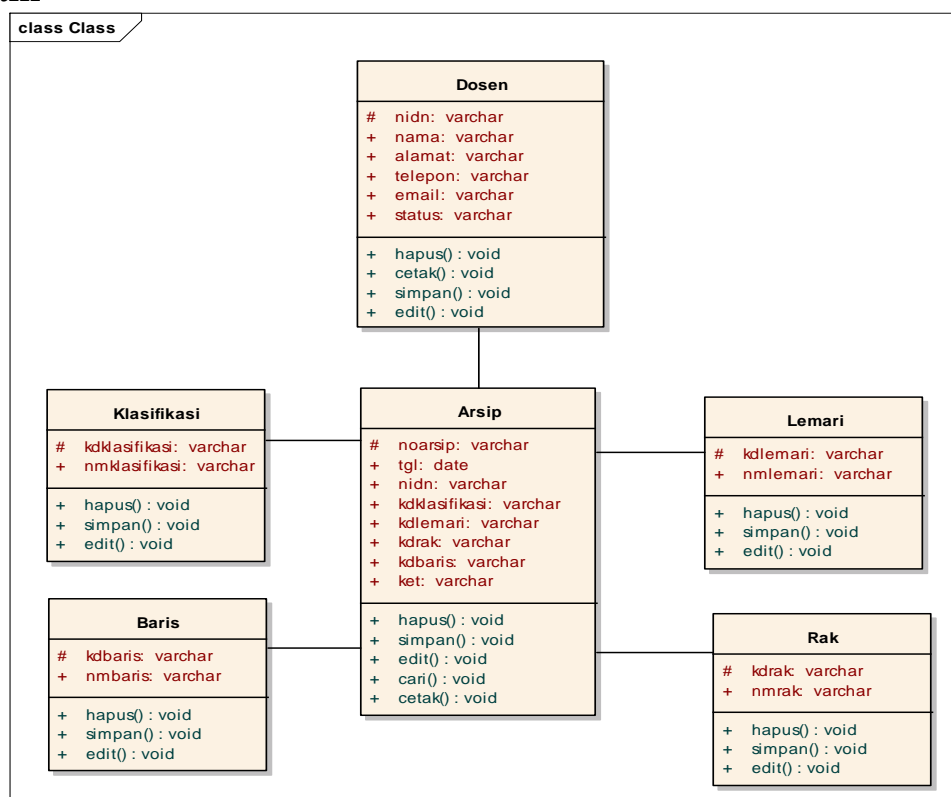

Gambar 3.5. Class Diagram 


\section{HASIL PENELITIAN DAN PEMBAHASAN}

\subsection{Home}

Halaman home seperti pada gambar 4.1 digunakan untuk mencari arsip dokumen kepegawaian Universitas Maritim AMNI Semarang.

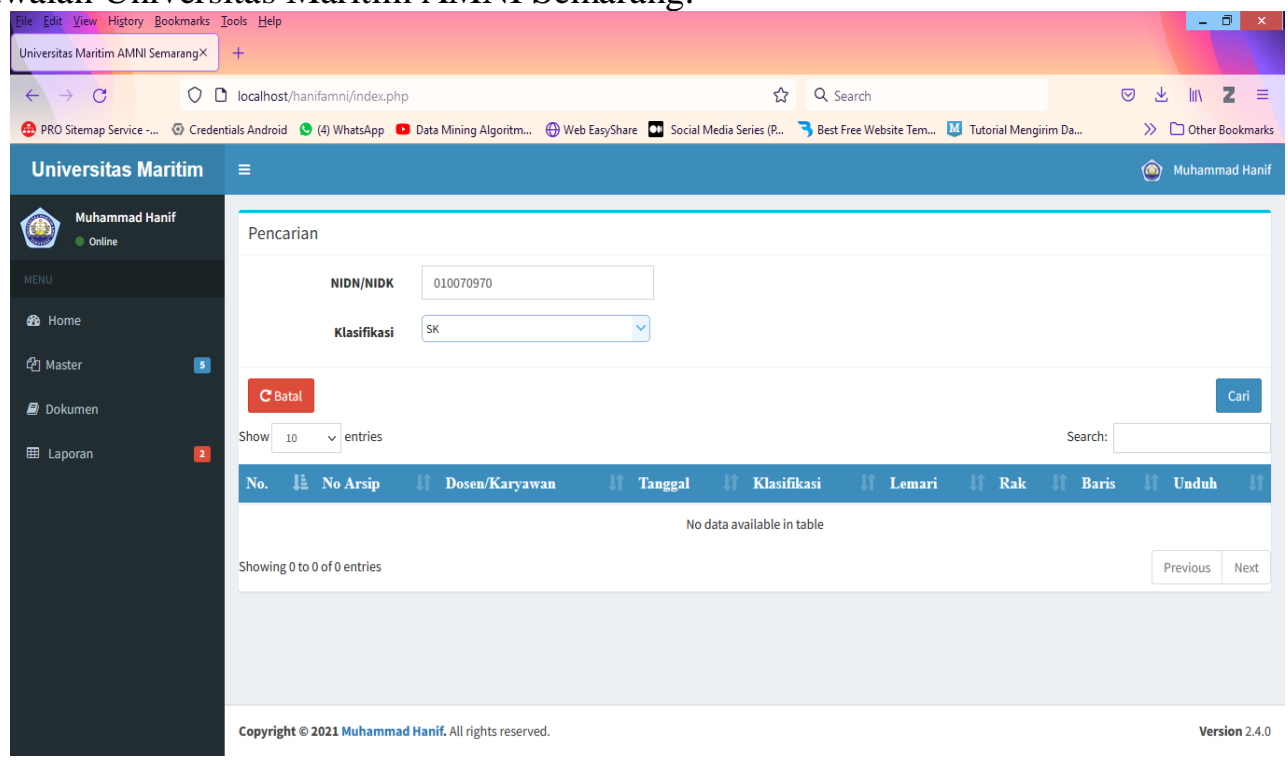

Gambar 4.1. Home

Untuk melakukan pencarian dokumen kepegawaian, dapat dicari berdasarkan klasifikasi dokumen kepegawaian dan NIDN atau NIDK. Masukkan data arsip dokumen kepegawaian yang dicari kemudian tekan tombol cari untuk mencari dokumen kepegawaian Universitas Maritim AMNI Semarang yang hasilnya diperlihatkan seperti gambar 4.2.

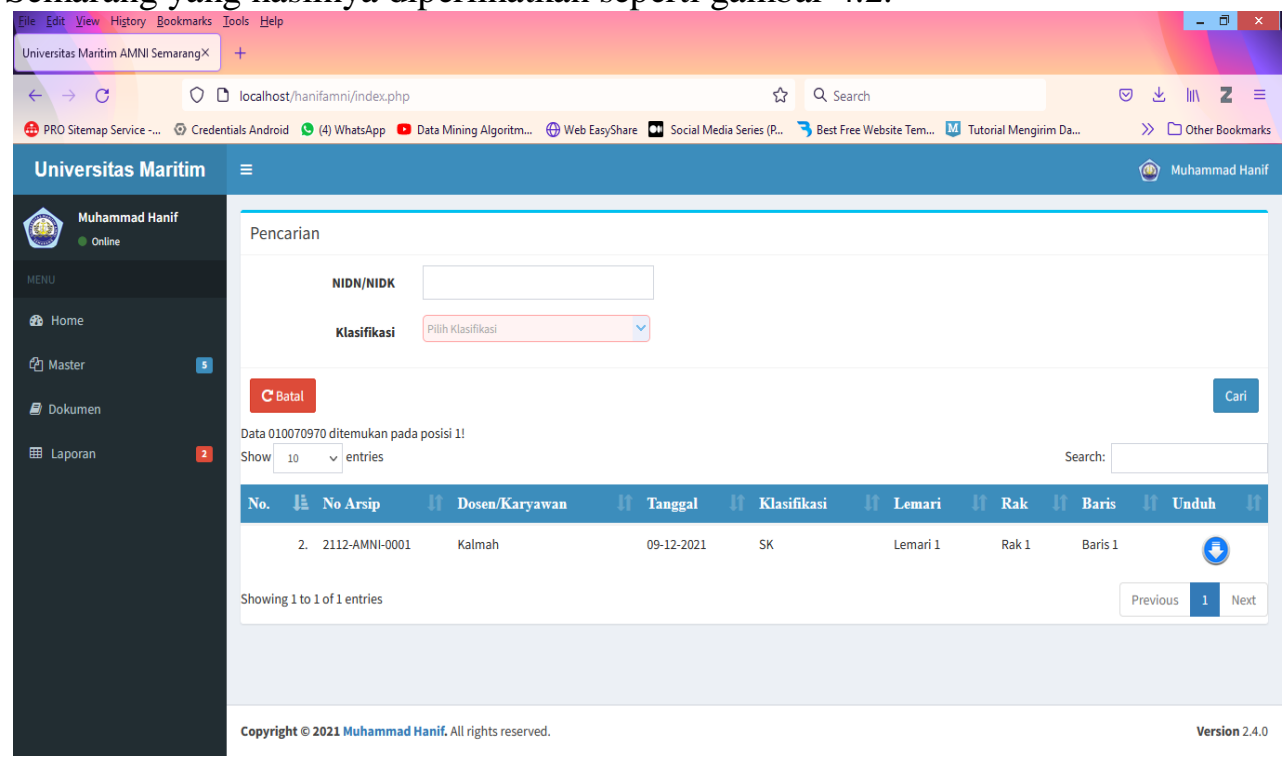

Gambar 4.2. Hasil Pencarian

Dokumen kepegawaian yang ditemukan akan ditampilkan dalam bentuk tabel yang terdiri dari nomor urut, nomor arsip, dosen/karyawan, tanggal, klasifikasi, lemari, rak, baris dan tombol unduh untuk mengunduh atau melihat isi dokumen kepegawaian seperti gambar 4.3. 


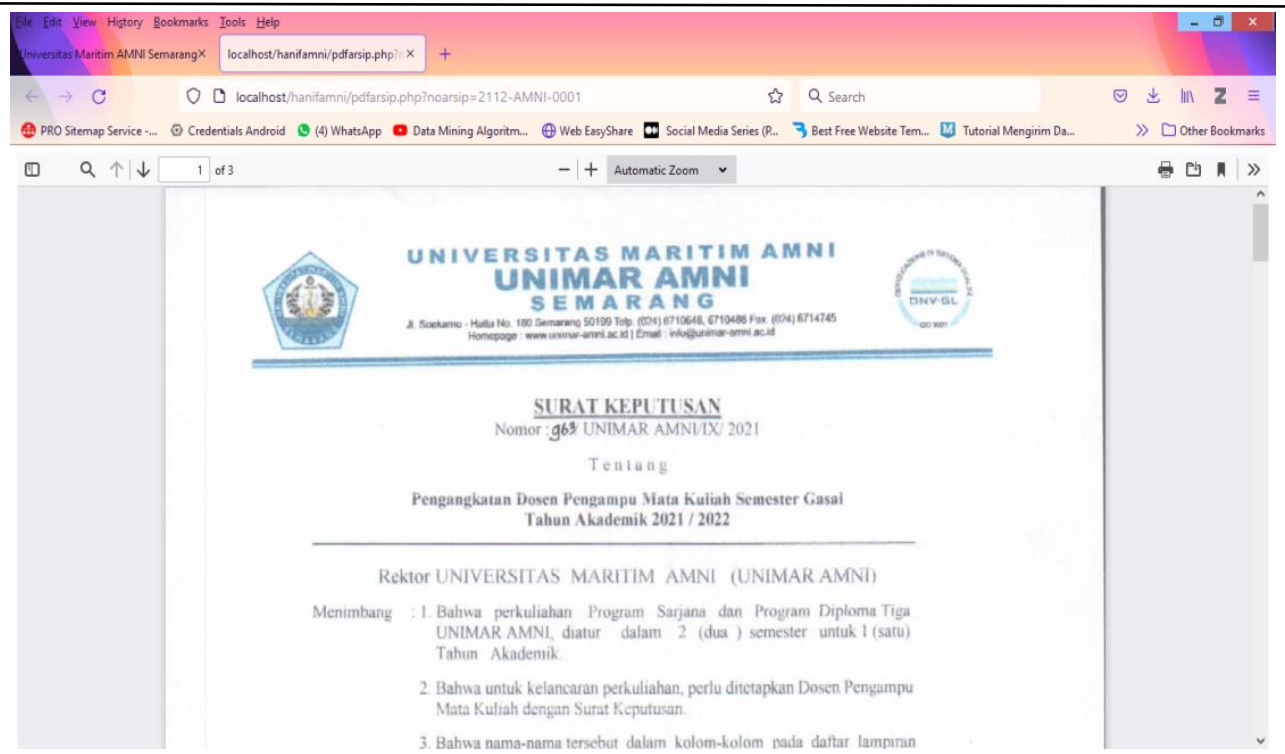

Gambar 4.3. Isi Dokumen Kepegawaian

Proses pencarian dokumen kepegawaian dengan algoritma sequential search untuk dokumen SK sebagai berikut:

1. Diketahui NIDN/NIDK yaitu
a. 010070968
b. 010070969
c. 010070970
d. 010070971
e. 010070972

2. NIDN/NIDK akan dibuat dalam bentuk array menjadi
$\mathrm{x}[0]=010070968$
$\mathrm{x}[1]=010070969$
$\mathrm{x}[3]=010070970$
$\mathrm{x}[4]=010070971$
$\mathrm{x}[5]=010070972$

3. Sebagai contoh, NIDN yang ingin dicari adalah 010070970, proses pencarian dengan algoritma sequential search yaitu

a. Proses pencarian array index ke-0 yaitu 010070968 dicocokan dengan NIDN yang akan dicari, jika tidak sama, maka mencari ke index berikutnya.

b. Proses pencarian array index ke-1 yaitu 010070969 juga bukan NIDN yang dicari, maka akan mencari lagi pada index berikutnya.

c. Proses pencarian array index ke-2 yaitu 010070970 merupakan NIDN yang dicari dan ditemukan, maka proses pencarian selesai dan keluar dari looping pencarian.

\subsection{Dokumen Kepegawaian}

Halaman dokumen seperti pada gambar 4.4 digunakan untuk memasukkan data dokumen kepegawaian Universitas Maritim AMNI Semarang. Nomor arsip akan terisi secara otomatis dengan format YYMM-AMNI-9999 dimana YYMM merupakan tahun dan bulan pengisian arsip dokumen kepegawaian dan 9999 merupakan urutan data dokumen kepegawaian dari tabel arsip. 


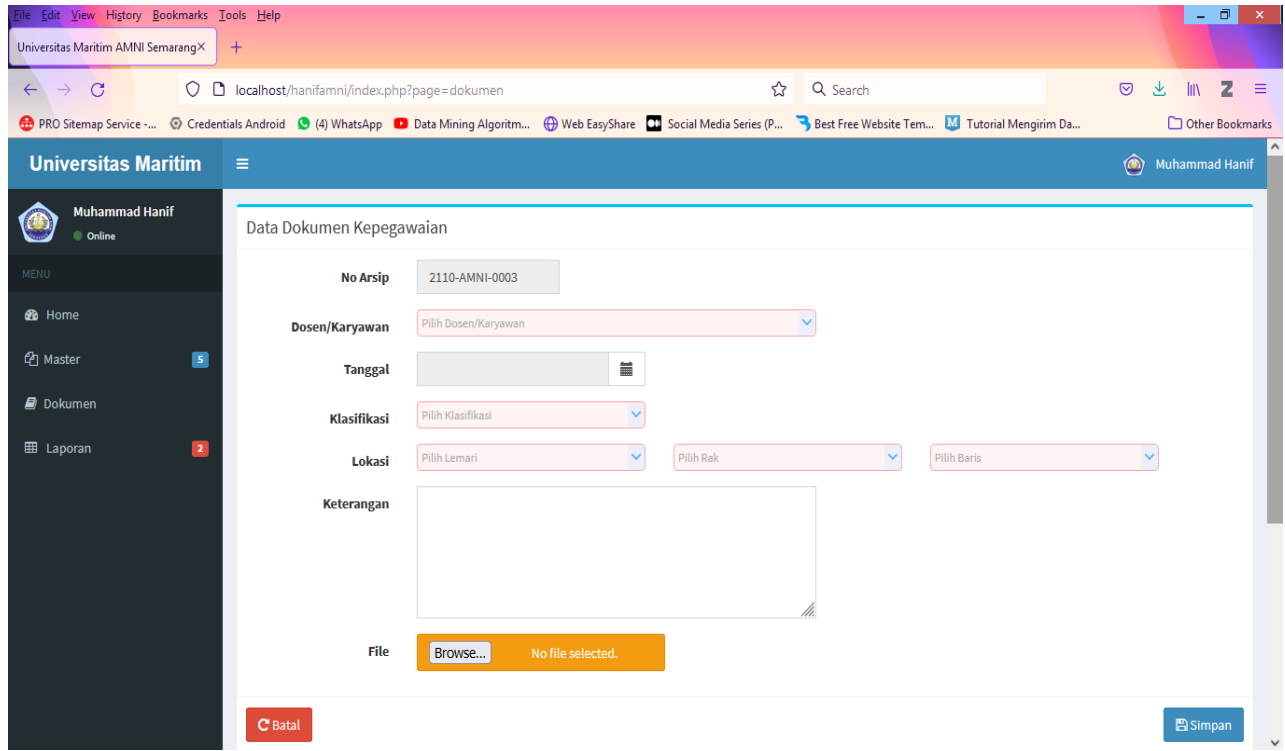

Gambar 4.4. Dokumen

Isi nomor arsip, dosen atau karyawan, tanggal, klasifikasi, lokasi, keterangan, file dalam bentuk pdf dan klik tombol simpan untuk menyimpan data dokumen kepegawaian Universitas Maritim AMNI Semarang. Klik tombol edit kemudian isi dosen atau karyawan, tanggal, klasifikasi, lokasi, keterangan, file dalam bentuk pdf dan klik tombol simpan untuk mengubah data dokumen kepegawaian Universitas Maritim AMNI Semarang. Klik tombol hapus dan pilih oke untuk menghapus data dokumen kepegawaian Universitas Maritim AMNI Semarang.

Dokumen kepegawaian Universitas Maritim AMNI Semarang harus diisi dalam bentuk format pdf, jika dokumen kepegawaian tidak dilampirkan pada saat pengisian data akan ditampilkan pesan seperti gambar 4.5.

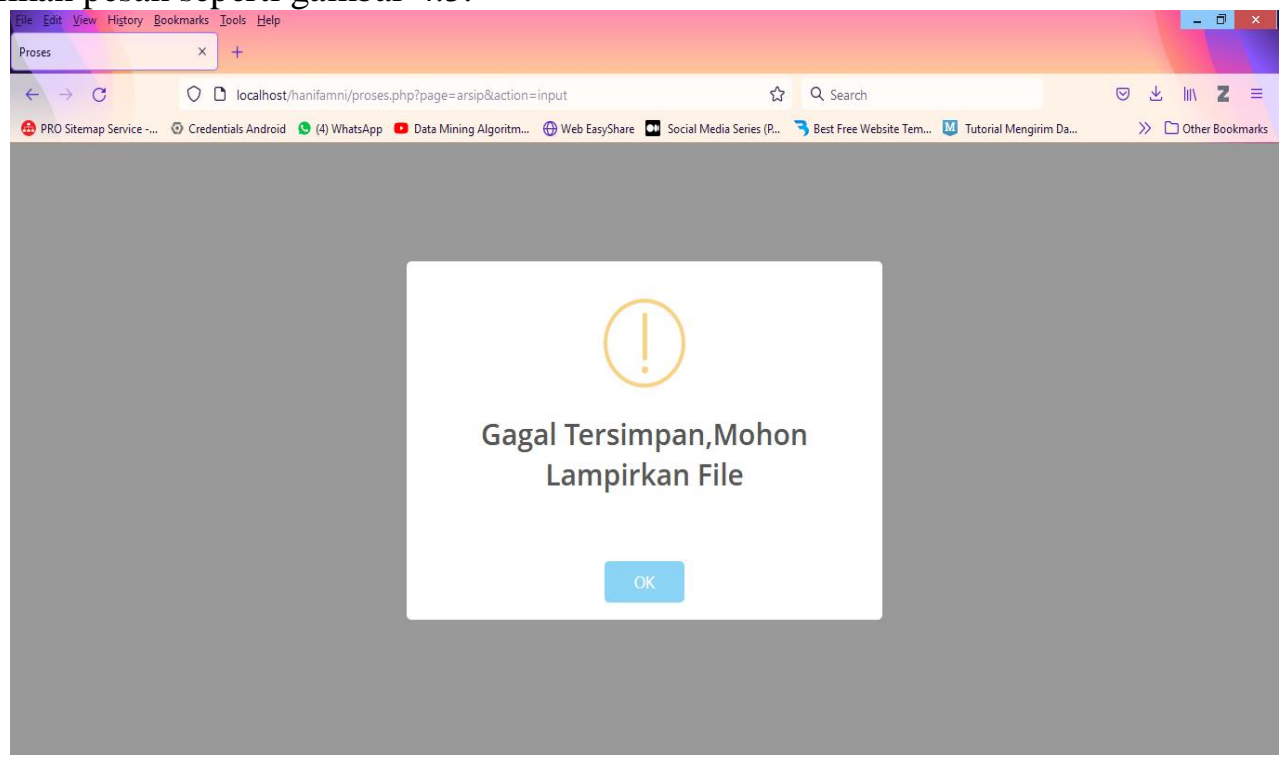

Gambar 4.5. Pesan Gagal Tersimpan

Dokumen kepegawaian Universitas Maritim AMNI Semarang harus diisi dalam bentuk format pdf, jika dokumen kepegawaian yang dilampirkan tidak dalam bentuk pdf pada saat pengisian data akan ditampilkan pesan seperti gambar 4.6. 


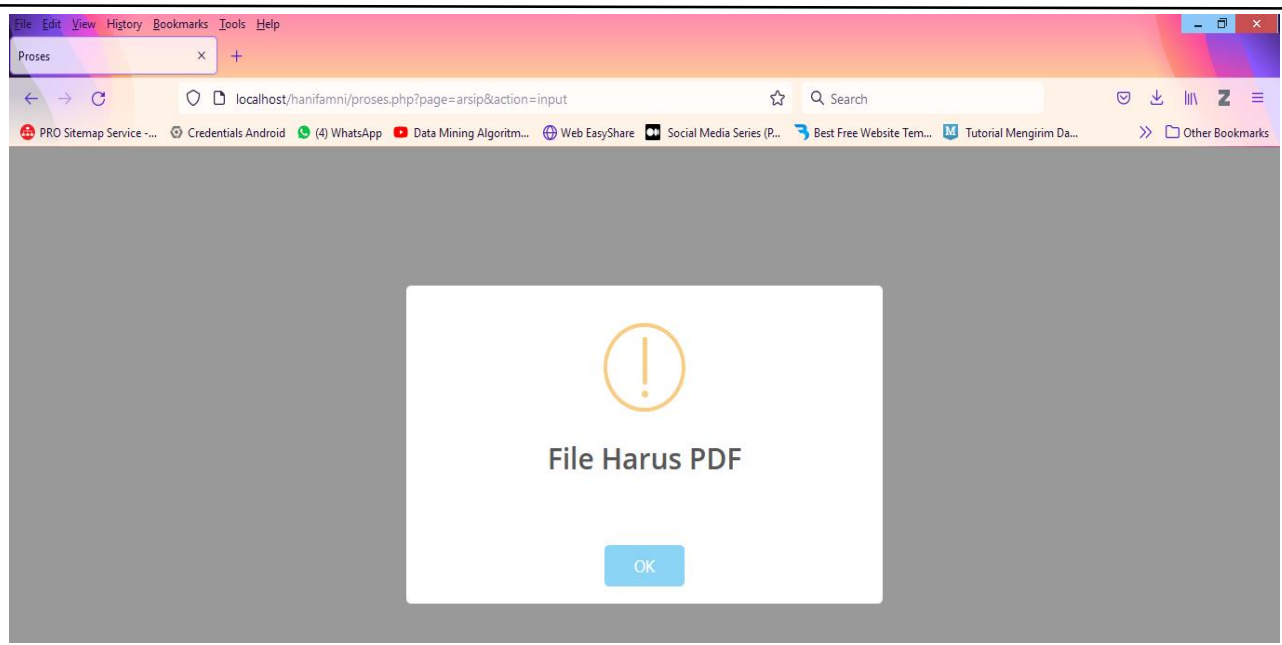

Gambar 4.6. Pesan File Harus PDF

Untuk melihat isi file dokumen kepegawaian, klik tombol unduh dan akan ditampilkan isi file dokumen kepegawaian seperti gambar 4.7.

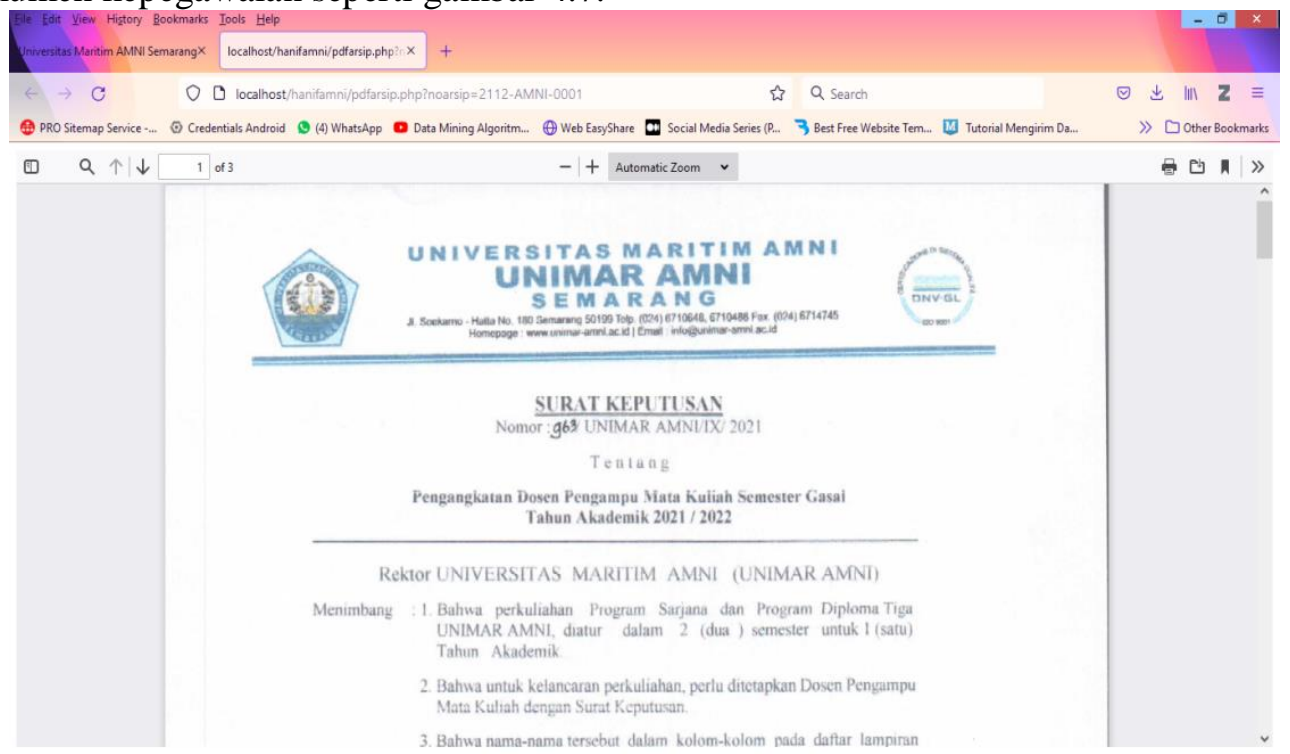

Gambar 4.7. Isi Dokumen Kepegawaian

\section{KESIMPULAN DAN SARAN}

Kesimpulan yang dapat diambil dari pembuatan sistem informasi kearsipan dokumen kepegawaian pada Universitas Maritim AMNI Semarang adalah sebagai berikut

1. Algoritma sequential search dapat di terapkan pada pencarian nomor dokumen kepegawaian pada Universitas Maritim AMNI Semarang dan berjalan dengan baik sesuai perencanaan

2. Sistem informasi kearsipan dokumen kepegawaian pada Universitas Maritim AMNI Semarang dapat digunakan mengelola arsip dokumen kepegawaian lebih maksimal, terkontrol, tertata dengan baik dan terawat sehingga arsip tidak mudah rusak

Saran yang dapat digunakan untuk pengembangan sistem informasi kearsipan dokumen kepegawaian pada Universitas Maritim AMNI Semarang selanjutnya yaitu sistem ini dapat ditambahkan pengelolaan arsip surat masuk, surat keluar 


\section{DAFTAR PUSTAKA}

[1] Muhammad Syarif Hidayatulloh, "Pengembangan Sistem Informasi Kearsipan Dinamis Di Dinas Perpustakaan Dan Kearsipan Kota Bandung." Akademi Sekretari Dan Manajemen Ariyanti Bandung, 2020.

[2] Zulkifli Amsyah, Manajemen Sistem Informasi. Jakarta: Gramedia Pustaka Utama, 2015.

[3] Rinaldi Munir and Leony Lidya, Algoritma dan Pemrograman Dalam Bahasa Pascal, C, dan C++ Edisi Keenam. Bandung: Informatika, 2016.

[4] Anisya Sonita and Mayang Sari, "Implementasi Algoritma Sequentialsearching Untuk Pencarian Nomor Surat Pada Sistem Arsip Elektronik," Jurnal Pseudocode, vol. 5, pp. 1-9, Feb. 2018.

[5] Marissa Utami and Yovi Apridiansyah, "Implementasi Algoritma Sequential Searching Pada Sistem Pelayanan Puskesmas Menggunakan Bootstrap (Studi Kasus Puskesmas Kampung Bali Bengkulu)," JSAI, vol. 2, pp. 81-86, Jan. 2019.

[6] Ibnu Fajar Shiddiq and Arita Witanti, "Aplikasi Kamus Bahasa Jawa Ngoko, Jawa Krama, dan Indonesia Berbasis Android Dengan Menggunakan Metode Sequential Search," Jurnal Multimedia \& Artificial Intelligence, vol. 2, pp. 21-28, Agustus 2018.

[7] Munawar, Analisis Perancangan Sistem Berorientasi Objek dengan UML (Unified Modeling Language). Bandung: Informatika, 2018. 